\title{
Adrenomedullin inhibits ovalbumin-induced bronchoconstriction and airway microvascular leakage in guinea-pigs
}

\author{
H. Ohbayashi, H. Suito, N. Yoshida, Y. Ilto, H. Kume, K-i. Yamaki
}

\begin{abstract}
Adrenomedullin inhibits ovalbumin-induced bronchoconstriction and airway microvascular leakage in guinea-pigs. H. Ohbayashi, H. Suito, N. Yoshida, Y. Ito, H. Kume, K-i. Yamaki. C) ERS Journals Ltd 1999.

ABSTRACT: Human adrenomedullin is a potent vasodilator with bronchodilation properties. The effects of adrenomedullin on antigen-induced bronchoconstriction and airway microvascular leakage in guinea-pigs was investigated. The portion of the adrenomedullin molecule possessing these pulmonary active profiles was also examined, using two truncated adrenomedullin molecules: adrenomedullin (1-25) and adrenomedullin (22-52).

Four weeks after sensitization with ovalbumin $\left(0.1 \mathrm{mg} \cdot \mathrm{kg}^{-1}\right)$, the guinea-pigs were anaesthetized and mechanically ventilated. Respiratory resistance, dynamic compliance and arterial blood pressure were monitored. Airway microvascular leakage was evaluated by extravasation of $20 \mathrm{mg} \cdot \mathrm{kg}^{-1}$ Evans blue into airway interstitial tissue. In order to enhance the pulmonary effects of adrenomedullin, the active production of endogenous nitric oxide was inhibited by coadministration of a nitric oxide synthase inhibitor, $L-N^{G}$-nitroarginine methethyl ester $\left(10 \mathrm{mg} \cdot \mathrm{kg}^{-1}\right)$.

Intravenous pretreatment with adrenomedullin $\left(10,30\right.$ and $\left.100 \mu \mathrm{g} \cdot \mathrm{mL}^{-1}\right)$ dosedependently inhibited ovalbumin-induced bronchoconstriction and airway microvascular leakage in all airway segments. Inhaled adrenomedullin $\left(100 \mu \mathrm{g} \cdot \mathrm{mL}^{-1}, 1 \mathrm{~min}\right)$ also significantly inhibited pulmonary changes induced by ovalbumin inhalation ( 3 $\left.\mathrm{mg} \cdot \mathrm{mL}^{-1}, 3 \mathrm{~min}\right)$. These pulmonary profiles of adrenomedullin were enhanced by inhibiting the active production of endogenous nitric oxide.

In conclusion, adrenomedullin has inhibitory effects on antigen-induced microvascular leakage and bronchoconstriction in guinea-pigs. These beneficial effects strongly related to its unique ring structure and $\mathrm{N}$-terminal segment, making it a potential anti-asthma. Eur Respir J 1999; 14: 1076-1081.
\end{abstract}

Internal Medicine II, Nagoya University School of Medicine, Nagoya, Japan

Correspondence: H. Ohbayashi Internal Medicine II

Nagoya University School of Medicine 65 Tsuruma-cho, Showa-ku Nagoya 466-0064

Japan

Fax: 0081527442175

Keywords: Adrenomedullin airway microvascular leakage bronchoconstriction

guinea-pig

nitric oxide

Received: December 91998

Accepted after revision May 101999
Human adrenomedullin, a peptide 52 amino acids in len$\mathrm{gth}$, is a potent vasodilator, initially isolated from human pheochromocytoma tissue [1]. Adrenomedullin shows structural homology, including a ring structure of six residues formed by an intermolecular disulphide linkage, with calcitonin gene-related peptide, one of the most potent vasodilator agents. Besides expression in the adrenal gland, adrenomedullin messenger ribonucleic acid (mRNA) has also been localized to cardiovascular tissue including the heart, kidney, lung and vascular wall [2]. Sugo and coworkers $[3,4]$ have demonstrated that cultured vascular cells, such as endothelial and vascular smooth muscle cells, have a prominent capacity to produce adrenomedullin. The lungs also express large amounts of adrenomedullin mRNA $[2,5]$ and adrenomedullin receptors $[6,7]$ on endothelial and vascular smooth muscle cells, suggesting that adrenomedullin may participate in the regulation of the pulmonary vascular system in an autocrine or paracrine manner. However, the pathophysiological role of adrenomedullin in the lung is still unclear.

Asthma is generally known as an inflammatory disease. Airway microvascular leakage, a primary feature of inflammation in asthma, is known to worsen the asthmatic condition. Increased microvascular leakage causes the formation of mucosal oedema and the exudation of plasma proteins into the bronchial interstitial tissue, accompanied by the activation of many biochemical pathways followed by bronchial narrowing and epithelial damage [8]. Under these conditions, the function of endothelial cells in pulmonary capillary vessels may play an important role in causing airway microvascular leakage. In a previous study, the potent inhibitory effects of natriuretic peptides against antigen-induced microvascular leakage and bronchoconstriction in the asthmatic model of guinea-pigs were reported [9]. The potent vasodilator action and the natriuretic and diuretic properties and potent vasodilative action of adrenomedullin are very similar to those of atrial natriuretic peptide (NAP) [10]. A previous study has shown that adrenomedullin significantly inhibits acetylcholine- and histamine-induced bronchoconstriction in a dose-dependent fashion [11]. These findings suggest that adrenomedullin might have similar effects to ANP on asthmatic changes.

In this study, the effects of adrenomedullin were first studied against both antigen-induced airway microvascular leakage and bronchoconstriction, and which portion of the adrenomedullin molecule possessed the pulmonary active profiles also investigated. However, when considering the complicated pathophysiological conditions of asthma, nitric oxide generation and its action cannot be neglected. In fact, exhaled NO is increased in allergen-induced experimental animals [12] as well as in patients with bronchial asthma 
[13]. Despite a potent bronchodilative effect [14], endogenous NO acts to increase airway microvascular leakage after airway allergic reaction [15] and might worsen the asthmatic condition. A recent study has reported that adrenomedullin augments inducible NO synthesis in interleukin-1 $\beta$-stimulated rat vascular smooth muscle, partially through a cyclic adenosine monophosphate (cAMP)dependent pathway [16]. These facts suggest that adrenomedullin-induced NO production might negate the beneficial effects of adrenomedullin on asthmatic reactions. However, there are no additional reports concerning the pulmonary effects of adrenomedullin on NO production in the pulmonary system. The second purpose of this study was to investigate whether or not L- $N^{\mathrm{G}}$-nitroarginine methethyl ester (L-NAME), a NO synthase inhibitor, could potentiate the effects of adrenomedullin on antigeninduced microvascular leakage.

\section{Materials and methods}

\section{Animal preparation}

Throughout the experiments, male Hartley guinea-pigs ( 250 g; Japan SLC, Inc., Shimoka, Japan) were used. In order to sensitize the animals, $0.5 \mathrm{~mL}$ saline containing 0.1 $\mathrm{mg}$ ovalbumin and $2 \mathrm{mg}$ aluminium hydroxide was first injected intraperitoneally. Then, once a week, intraperitoneal injections of $0.1 \mathrm{mg}$ ovalbumin dissolved in $0.5 \mathrm{~mL}$ $0.9 \%$ saline were given. Three weeks later, guinea-pigs, then weighing 350-450 g, were given intraperitoneal injections of pentobarbital sodium $\left(50 \mathrm{mg} \cdot \mathrm{kg}^{-1}\right)$ for anaesthesia. Evidence of the appropriate level of anaesthesia was shown by the disappearance of the corneal reflex and a lack of the withdrawal response to paw pinching. A tracheal cannula ( $7 \mathrm{~mm}$ length and $2.0 \mathrm{~mm}$ internal diameter) was inserted through a tracheostomy and connected to a constant-volume respirator (Model 683; Harvard Apparatus, South Natick, MA, USA) keeping mechanical ventilation at a tidal volume of $10 \mathrm{~mL} \cdot \mathrm{kg}^{-1}$ and a frequency of 60 breaths $\cdot \min ^{-1}$. To administer the drugs and to measure systemic blood pressure, a jugular vein and a carotid artery were respectively cannulated. The animals were placed in a plethysmograph box (Model PLYAN; Buxco Electronics, Inc., Sharon, CT, USA). Signals from the plethysmograph box and catheters were sensed by differential pressure transducers, and monitored by a pulmonary mechanics analyser (Buxco Model 6). All the signals were recorded using a multichannel recorder (Linearcorder F WR3701; Graphtec Co. Ltd., Tokyo, Japan) and all signals were calculated. This study was performed in accordance with the guidelines for animal experimentation set by Nagoya University School of Medicine.

\section{Protocol}

The effects of adrenomedullin on antigen-induced airway changes were studied in 51 sensitized guinea-pigs. The animals were randomly divided into nine groups (with five (groups 1-7) or eight (groups 8-9) animals per group): group 1) ovalbumin alone $\left(1 \mathrm{mg} \cdot \mathrm{kg}^{-1}\right.$ i.v. $)$ as antigen challenge; groups 2-4) adrenomedullin (10,30 and $100 \mu \mathrm{g} \cdot \mathrm{kg}^{-1}$ i.v., respectively); group 5) adrenomedullin (1-25) (100 $\mu \mathrm{g} \cdot \mathrm{kg}^{-1}$ i.v. $)$; group 6) adrenomedullin (22-52) $\left(100 \mu \mathrm{g} \cdot \mathrm{kg}^{-1}\right.$ i.v.); group 7) saline vehicle containing $20 \mathrm{mg} \cdot \mathrm{kg}^{-1}$ Evans blue as the basal control; group 8) adrenomedullin (100 $\mu \mathrm{g} \cdot \mathrm{kg}^{-1}$ i.v.) and L-NAME (10 $\mathrm{mg} \cdot \mathrm{kg}^{-1}$ i.v. $)$; and group 9) adrenomedullin $\left(100 \mu \mathrm{g} \cdot \mathrm{kg}^{-1} i . v\right.$. $)$, L-NAME $\left(10 \mathrm{mg} \cdot \mathrm{kg}^{-1}\right.$ i.v.) and L-arginine $\left(100 \mathrm{mg} \cdot \mathrm{kg}^{-1}\right.$ i.v. $)$.

To eliminate the haemodynamic effects of intravenous adrenomedullin administration, the following aerosol experimental protocol (eight animals per group) was undertaken: group a) preadministration of inhaled adrenomedullin $\left(100 \mu \mathrm{g} \cdot \mathrm{mL}^{-1}, 1 \mathrm{~min}\right)$ followed by inhaled ovalbumin (3 $\left.\mathrm{mg} \cdot \mathrm{mL}^{-1}, 3 \mathrm{~min}\right)$; and group b) preadministration of inhaled saline (1 min) followed by inhaled ovalbumin (3 $\left.\mathrm{mg} \cdot \mathrm{mL}^{-1}, 3 \mathrm{~min}\right)$. All inhalation procedures were performed using an ultrasonic nebulizer (mean particle size $\sim 5 \mu \mathrm{m}$ as per the manufacturer's specification) (NE-U07; Omron Co. Ltd., Tokyo, Japan). The output of this nebulizer was measured as, $0.2 \mathrm{~mL} \cdot \mathrm{min}^{-1}$ at $4 \mathrm{~mL}$ tidal volume when attached to the ventilatory system.

\section{Measurement of pulmonary mechanics and mean blood} pressure in antigen-induced bronchoconstriction

The animals were given $1 \mathrm{mg} \cdot \mathrm{kg}^{-1}$ of mepyramine maleate $i . v$. before antigen challenge to avoid anaphylaxis. Baseline recordings of pulmonary mechanics (respiratory resistance and dynamic compliance) and mean blood pressure were obtained. Then L-NAME (groups 8 and 9) or $1 \mathrm{~mL} \cdot \mathrm{kg}^{-1}$ saline (all other groups) was administered i.v. After the increase in systemic blood pressure induced by LNAME reached a plateau at 5-6 min, or after the same time period in the vehicle group, each dose of the peptides was injected i.v. $1 \mathrm{~min}$ before challenge with the antigen. Larginine was also administered to group 9 at the peak time of blood pressure response to L-NAME. Respiratory resistance, dynamic compliance and mean blood pressure were recorded for $10 \mathrm{~min}$.

In the second protocol, baseline recordings of pulmonary mechanics and mean blood pressure were made, and then the animals pretreated with $1 \mathrm{mg} \cdot \mathrm{kg}^{-1}$ i.v. mepyramine maleate $5 \mathrm{~min}$ before starting the ovalbumin inhalation challenge. Adrenomedullin $\left(100 \mu \mathrm{g} \cdot \mathrm{mL}^{-1}, 1 \mathrm{~min}\right)$ or vehicle (saline, $1 \mathrm{~min}$ ) was inhaled 3 min before antigen inhalation. An ovalbumin aerosol $\left(3 \mathrm{mg} \cdot \mathrm{mL}^{-1}\right)$ was administered for the first $3 \mathrm{~min}$ while recording pulmonary mechanics and mean blood pressure for $10 \mathrm{~min}$.

\section{Quantitative analysis of airway microvascular leakage}

Microvascular leakage was quantified using an index of airway vascular permeability involving the extravasation of Evans blue into airway interstitial tissue, since it correlates with the extravasation of radiolabelled albumin in guinea-pig airways [17]. In order to evaluate the relationship between microvascular permeability and bronchoconstriction, a technique was used that allowed measurement of both bronchoconstriction and airway microvascular leakage in the same animal. The animal was exsanguinated, and the chest cavity opened immediately after measuring antigen-induced bronchoconstriction. Saline $(50 \mathrm{~mL}$, $0.9 \%$ ) was perfused at a pressure of $120 \mathrm{mmHg}$ from the pulmonary artery into the left atrium in order to eliminate excess Evans blue in the pulmonary circulation. The airway and lungs were then removed, and the extraneous connective tissues, vasculature and parenchyma gently scraped off using a blunt scalpel until only bronchial tissue remained. The airways were divided into three 
portions: the trachea, main bronchi and intrapulmonary airways. Each tissue piece was weighed wet and then soaked in $2 \mathrm{~mL}$ formamide for $24 \mathrm{~h}$ at $37^{\circ} \mathrm{C}$ to extract the Evans blue. The amount of Evans blue extracted was determined by measuring the optical density at $600 \mathrm{~nm}$ using a spectrophotometer (enzyme immunoassay plate reader, ELNX 96; Metertech, Inc., Taipei, Taiwan). Evans blue extravasation was calculated by interpolation on a standard curve constructed using five known dye concentrations in the range $0.5-10 \mu \mathrm{g} \cdot \mathrm{mL}^{-1}$, and the result expressed in ng.mg wet tissue weight ${ }^{-1}$.

\section{Drugs and chemicals}

The following drugs and chemicals were used: adrenomedullin, adrenomedullin (1-25) and adrenomedullin (2252) were purchased from Peptide Institute, Inc. (Osaka, Japan); L-NAME, L-arginine, chicken ovalbumin, formamide and Evans blue from Waco Pure Chemical Co. (Osaka, Japan); aluminium, hydroxide from Katayama Chemical Co. (Osaka, Japan); and mepyramine maleate from Cosmobio Co. (Tokyo, Japan). All agents were dissolved in $0.9 \%$ saline.

\section{Statistical analysis}

All data are expressed as mean \pm SD. Statistical comparisons were made using either the unpaired Student's t-test (two-tailed) or two-way analysis of variance followed by Dunnett's t-test. The mean blood pressure was calculated from recorded traces as diastolic blood pressure +0.33 (systolic blood pressure - diastolic blood pressure). A pvalue $<0.05$ were considered statistically significant.

\section{Results}

In a preliminary study, with no antigen challenge, it was ascertained that the intravenous administration of adrenomedullin $\left(100 \mu \mathrm{g} \cdot \mathrm{kg}^{-1}\right.$ i.v., $\left.\mathrm{n}=4\right)$ or $\mathrm{L}$-arginine $\left(100 \mathrm{mg} \cdot \mathrm{kg}^{-1}\right.$ i.v., $\mathrm{n}=5$ ) showed no statistically significant effect on airway microvascular leakage and bronchoconstriction, and $\mathrm{L}-\mathrm{NAME}\left(10 \mathrm{mg} \cdot \mathrm{kg}^{-1}\right.$ i.v., $\left.\mathrm{n}=5\right)$ showed no statistically significant effect on bronchoconstriction (data not shown).
Measurement of pulmonary mechanics and mean blood pressure in antigen-induced bronchoconstriction

The administration of $1 \mathrm{mg} \cdot \mathrm{kg}^{-1}$ ovalbumin caused significant bronchoconstriction, which reached a maximum within 4 min of injection. The effect of adrenomedullin on respiratory resistance, an index of central airway constriction, is shown in figure 1a. The effect of adrenomedullin on dynamic compliance, an index of peripheral airway constriction, is shown in figure $1 \mathrm{~b}$. Intravenous pretreatment with adrenomedullin significantly reduced ovalbumin-induced bronchoconstriction in a dose-dependent manner. As shown in figure $2 \mathrm{a}$ and $\mathrm{b}$, the $\mathrm{C}$-terminal portion of the adrenomedullin molecule (adrenomedullin (22-52)) had a significantly lower pulmonary active profile than adrenomedullin, especially during the first $5 \mathrm{~min}$, whereas adrenomedullin (1-25) clearly retained these bronchodilative actions. As demonstrated in figure $3 \mathrm{a}$ and $\mathrm{b}$, the NO synthase inhibitor L-NAME inhibited bronchodilation caused by adrenomedullin, but with no statistical significance. The suppressive effect of L-NAME was rendered ineffective by $100 \mathrm{mg} \cdot \mathrm{kg}^{-1} \mathrm{~L}$-arginine.

Inhaled ovalbumin (3 $\left.\mathrm{mg} \cdot \mathrm{mL}^{-1}, 3 \mathrm{~min}\right)$ caused significant bronchoconstriction, which was significantly inhibited by pretreatment with inhaled adrenomedullin as shown in figure $4 \mathrm{a}$ and $\mathrm{b}$.

\section{Quantitative analysis of airway microvascular leakage}

Intravenous administration of ovalbumin produced significant increases in extravasated Evans blue in the trachea, main bronchi and intrapulmonary airways $(p<0.001)$, and pretreatment with adrenomedullin significantly inhibited ovalbumin-induced plasma leakage at all three airway levels in a dose-dependent manner (fig. 1c). Both portions of the adrenomedullin molecule (adrenomedullin (1-25) and adrenomedullin (22-52)) showed significantly lower pulmonary active profiles in comparison to adrenomedullin (fig. 2c). L-NAME significantly enhanced the inhibitory effect of adrenomedullin on ovalbumin-induced microvascular leakage, especially in the trachea and main bronchi. This enhancement of adrenomedullin action by
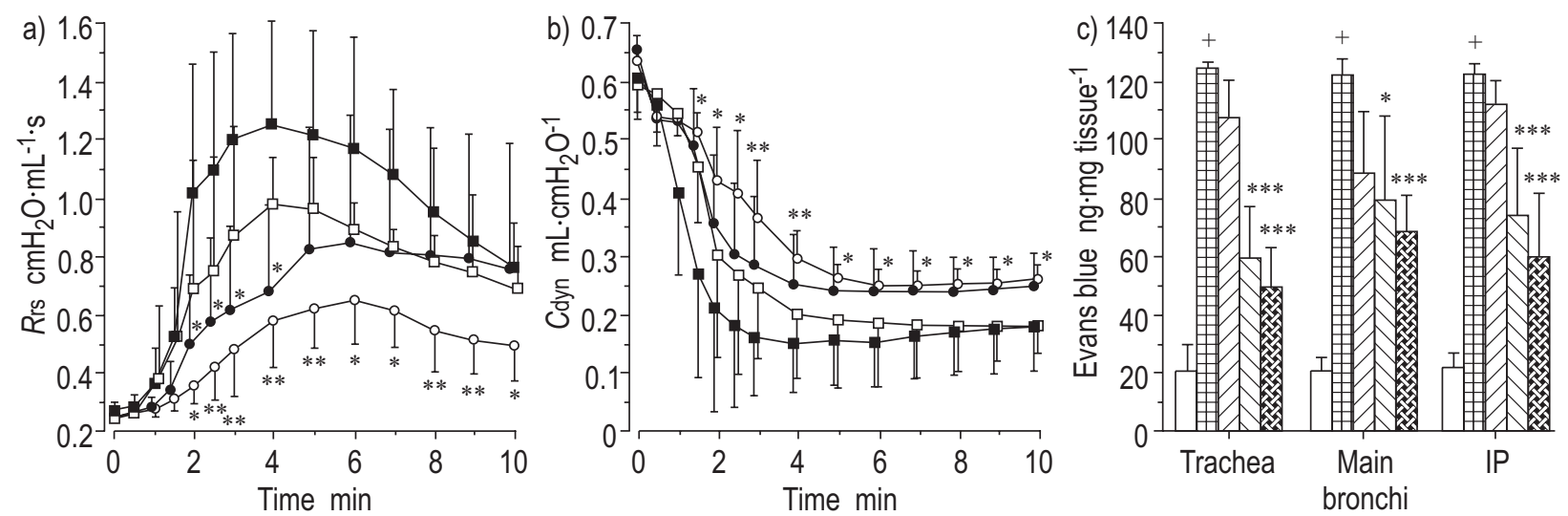

Fig. 1. - Time course of the inhibitory effects of adrenomedullin on the antigen-induced: a) increase in respiratory resistance (Rrs); and b) decrease in dynamic compliance $\left(C\right.$ dyn). Adrenomedullin $\left(\bigcirc: 100 \mu \mathrm{g} \cdot \mathrm{kg}^{-1} ; 0: 30 \mu \mathrm{g}^{-1} \mathrm{~kg}^{-1} ; \square: 10 \mu \mathrm{g}^{-1} \mathrm{~kg}^{-1}\right.$ ) dose-dependently inhibited ovalbumin-induced bronchoconstriction ( $\mathbf{\square}$ ) c) Effect of adrenomedullin on microvascular leakage induced by ovalbumin challenge at different airway levels in sensitized guinea-pigs. Intravenous pretreatment with adrenomedullin ( $: 100 \mu \mathrm{g} \cdot \mathrm{kg}^{-1} ; \mathbb{\mathbb { N }}: 30 \mu \mathrm{g} \cdot \mathrm{kg}^{-1} ; \mathbb{Z}: 10 \mu \mathrm{g} \cdot \mathrm{kg}^{-1}$ ) significantly reduced the microvascular permeability of each airway level in a dose-dependent manner. $\square$ : basal control (vehicle); 卌: ovalbumin challenge. Data are presented as (n=5). IP: intrapulmonary. ${ }^{*}: \mathrm{p}<0.05 ; * *: \mathrm{p}<0.01 ; * * *: \mathrm{p}<0.001$ compared with ovalbumin challenge; ${ }^{+}: \mathrm{p}<0.001$ compared with basal control. 

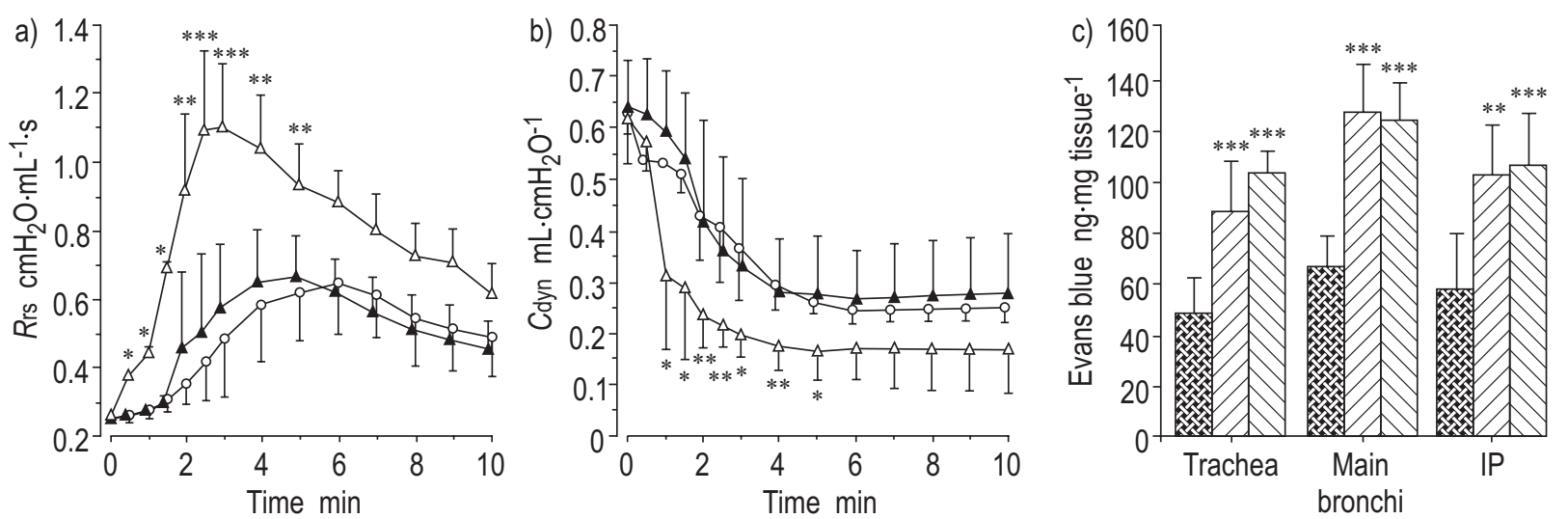

Fig. 2. - Time course comparing the effects of adrenomedullin $(\bigcirc)$, adrenomedullin $(1-25)(\mathbf{\Delta})$ and adrenomedullin $(22-52)(\triangle)\left(\right.$ all $\left.100 \mu \mathrm{g} \cdot \mathrm{kg}^{-1}\right)$ on the antigen-induced: a) increase in respiratory resistance $(R \mathrm{rs})$; and b) decrease in dynamic compliance $(C$ dyn). c) Effects of adrenomedullin (读), adrenomedullin $(1-25)(\mathbb{Z})$ and adrenomedullin $(22-52)(\mathbb{Q})$ on antigen-induced microvascular leakage. Data are presented as mean $\pm \mathrm{SD}(\mathrm{n}=5)$. IP: intrapulmonary. $*: \mathrm{p}<0.05 ; * *: \mathrm{p}<0.01, * * *: \mathrm{p}<0.001$ compared with adrenomedullin.

L-NAME was inhibited by coadministration of L-arginine (fig. 3c).

Inhaled ovalbumin produced significant increases in extravasated Evans blue in the trachea, main bronchi and intrapulmonary airways, and pretreatment with adrenomedullin significantly inhibited ovalbumin-induced plasma leakage at all three airway levels in a dose-dependent manner (fig. 4c).

\section{Changes in mean blood pressure}

Table 1 shows changes in mean blood pressure. Following intravenous treatment with adrenomedullin (30 and 100 $\left.\mu \mathrm{g} \cdot \mathrm{kg}^{-1}\right)$, there was a significant reduction in mean blood pressure. However, two truncated adrenomedullin molecules, adrenomedullin (1-25) and adrenomedullin (22-52), showed no significant systemic vasodepression. L-NAME pretreatment, which significantly increased mean blood pressure, was reversed by a $100 \mathrm{mg} \cdot \mathrm{kg}^{-1}$ injection of Larginine. Conversely, inhaled adrenomedullin showed no significant decrease in systemic mean blood pressure: $55.12 \pm 9.32 \mathrm{mmHg}$ before versus $54.40 \pm 10.29 \mathrm{mmHg}$ after treatment with inhaled adrenomedullin $(\mathrm{p}=0.894)$.

\section{Discussion}

This study demonstrated the potent inhibitory effects of adrenomedullin on both antigen-induced bronchoconstriction (fig. 1a and b) and airway microvascular leakage (fig. 3a) in actively sensitized guinea-pig, and that these potencies were due to the segmental structure of the adrenomedullin molecule. In a previous study, KANAZAWA et al. [11] first demonstrated that adrenomedullin, a well-known strong vasodilator, could also dilate smooth airway muscle. The significant inhibitory effects on histamine- and acetylcholine-induced bronchoconstriction encouraged the further research into the antigen-induced asthmatic responses in sensitized guinea-pigs described in this study. In the present study, the dose-dependent bronchodilative effect of adrenomedullin on airway smooth muscle in guinea-pigs was shown, and that this may be similar to the cAMP-linked mechanism of adrenomedullin-mediated vasodilation in vascular smooth muscle cells [18]. The potent vasodilative effect of intravenous adrenomedullin also caused a reduction in systemic mean blood pressure (table 1). The systemic vasodepressive responses to adrenomedullin are reported to have prolonged
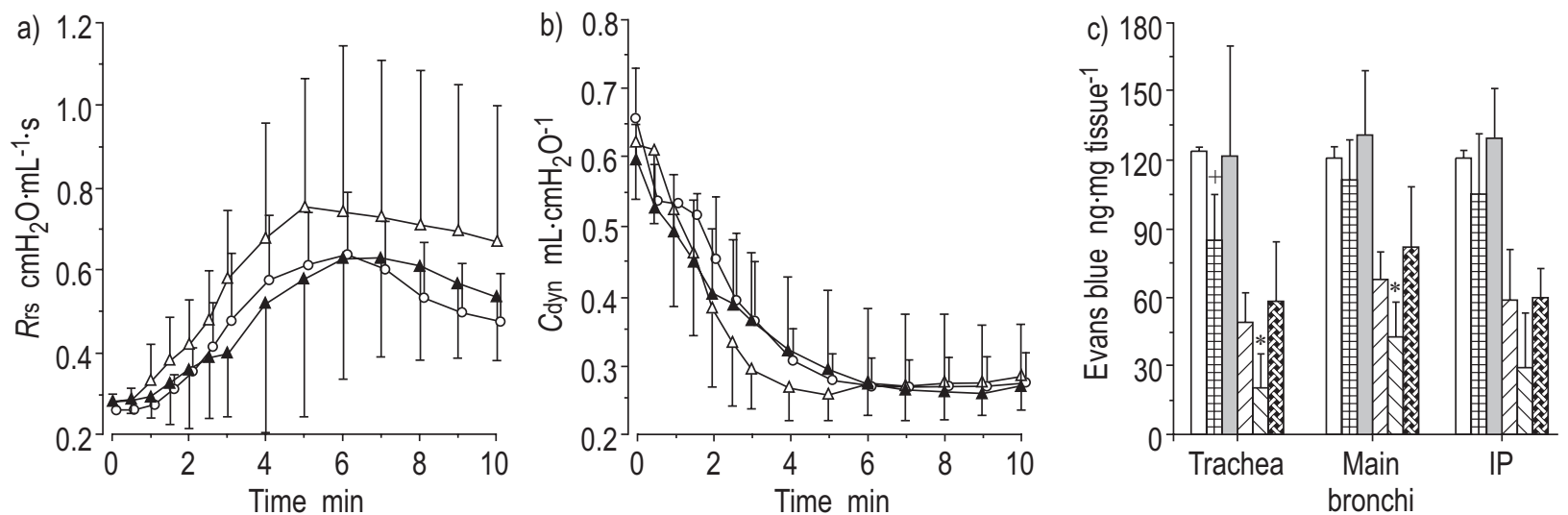

Fig. 3. - Effect of pretreatment with $\mathrm{L}-N^{\mathrm{G}}$-nitroarginine methethyl ester (L-NAME, $\left.\triangle, 10 \mathrm{mg} \cdot \mathrm{kg}^{-1}\right)$ and $\mathrm{L}-\mathrm{NAME}+\mathrm{L}-\mathrm{arginine}\left(\boldsymbol{\Delta}\right.$, $\left.100 \mathrm{mg} \cdot \mathrm{kg}^{-1}\right)$ on adrenomedullin inhibition of the ovalbumin-induced: a) increase in respiratory resistance (Rrs); and b) decrease in dynamic compliance (Cdyn). Pretreatment had no significant effect on the inhibitory action of adrenomedullin $\left(\bigcirc, 100 \mathrm{mg} \cdot \mathrm{kg}^{-1}\right)$. c) Reduction by adrenomedullin of the antigeninduced increase in microvascular leakage at different airway levels in sensitized guinea-pigs. $\square$ : ovalbumin challenge group; 贯: pretreatment with L-

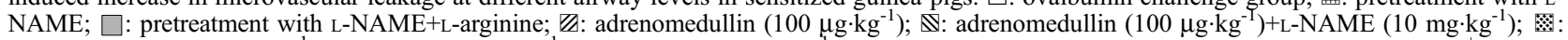
adrenomedullin $\left(100 \mu \mathrm{g} \cdot \mathrm{kg}^{-1}\right)+\mathrm{L}-\mathrm{NAME}\left(10 \mathrm{mg} \cdot \mathrm{kg}^{-1}\right)+\mathrm{L}$-arginine $\left(100 \mathrm{mg} \cdot \mathrm{kg}^{-1}\right)$. Data are presented as mean $\pm \mathrm{SD}(\mathrm{n}=8)$. IP: intrapulmonary. ${ }^{+}: \mathrm{p}<0.01$ compared with ovalbumin challenge; *: $\mathrm{p}<0.05$ compared with adrenomedullin. 

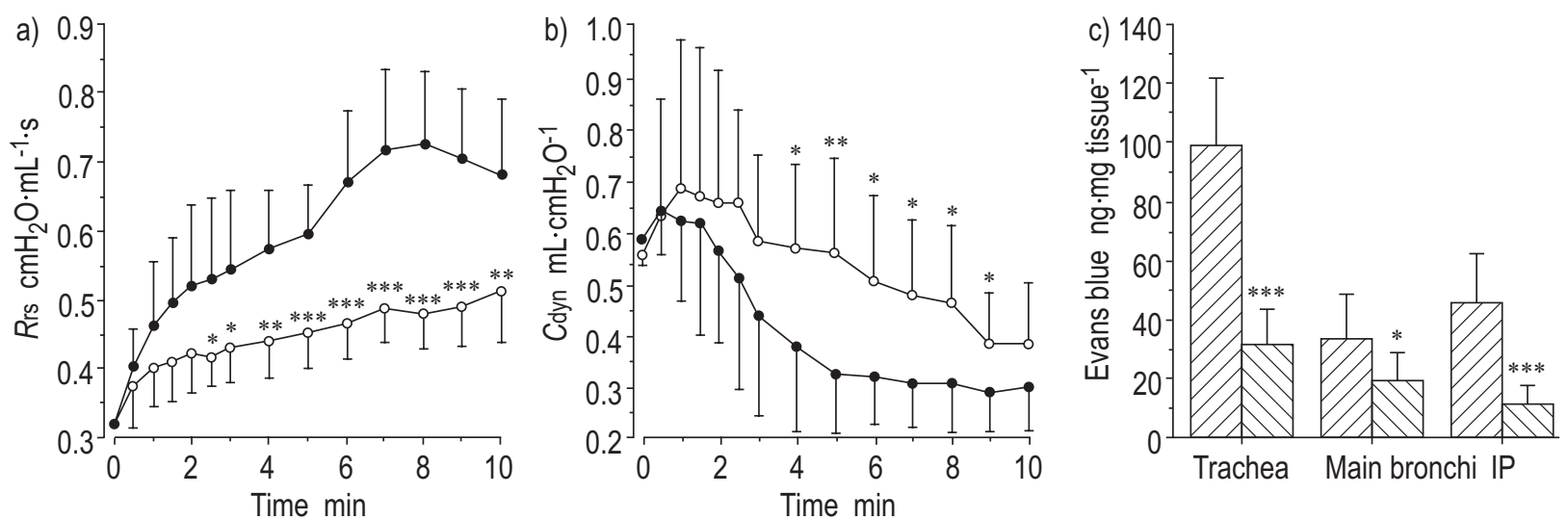

Fig. 4. - Time course of the inhibitory effects of inhaled adrenomedullin on the aerosol ovalbumin-induced: a) increase in respiratory resistance (Rrs); and b) decrease in dynamic compliance $(C$ dyn $)$. Adrenomedullin $\left(\bigcirc, 100 \mu \mathrm{g} \cdot \mathrm{kg}^{-1}\right)$ significantly inhibited aerosol ovalbumin-induced bronchoconstriction (O). c) Effect of inhaled adrenomedullin on microvascular leakage induced by aerosol ovalbumin at different airway levels. $\mathbb{Z}$ : inhaled ovalbumin

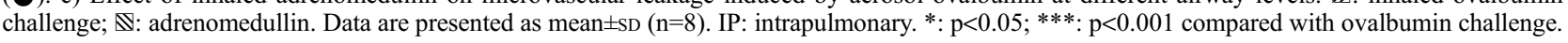

action, whereas pulmonary vasodepressive activities in the pulmonary vascular bed are rapid in onset and short in duration in both the anaesthetized rat [1] and the intact cat [19]. The reason for this differential result in the time course is still unclear. Indeed, the short-duration pulmonary vasodilation might change blood flow, and in turn alter airway microvascular leakage. The systemic haemodynamic influences were eliminated in order to evaluate the effects of adrenomedullin alone. The potent inhibitory effects of inhaled adrenomedullin on aerosol ovalbumin-induced bronchoconstriction and airway microvascular leakage were demonstrated (fig. 4). Microvascular leakage appears to occur primarily in capillary vessels which have no vascular smooth muscle, suggesting that endothelial cells are involved in the inhibitory effect on microvascular leakage. The fact that endothelial cells possess adrenomedullin receptors and synthesize adrenomedullin also indicates the existence of mechanisms in the pulmonary circulation which regulate airway microvascular permeability. Although the distinct mechanism is still unknown, SHIMEKAKE et al. [20] demonstrated that adrenomedullin induced a dose-dependent increase in intracellular free $\mathrm{Ca}^{2+}$ in endothelial cells, resulting from phospholipase $\mathrm{C}$ activation and inositol 1,4,5-triphosphate formation. Intracellular calcium modulation by adrenomedullin may be an important factor in the maintenance of the cytoskeleton and gap junctions, including those of endothelial cells.

To investigate the relationship between the structure and inhibitory properties of adrenomedullin in asthmatic conditions, adrenomedullin was compared with two truncated adrenomedullin molecules: adrenomedullin (1-25) and adrenomedullin (22-52). Adrenomedullin (1-25) had the unique ring structure and N-terminal amide of the adrenomedullin molecule, and showed as potent an inhibitory effect on ovalbumin-induced bronchoconstriction as did the whole adrenomedullin molecule, but adrenomedullin (22-52) showed little inhibitory effect (fig. 2a and b). This indicates that the portions of the adrenomedullin molecule found in adrenomedullin (1-25) are needed to suppress the bronchoconstriction. As for the inhibitory effect of adrenomedullin on airway microvascular permeability, the whole of the adrenomedullin molecule was necessary for sufficient inhibition of airway microvascular leakage (fig. 2c). These results suggest that the mechanism of the inhibitory effect on airway microvascular leakage might differ from that which inhibits bronchoconstriction. Other studies have indicated that adrenomedullin (13-52), rather than adrenomedullin (1-12), is responsible for the marked pulmonary vasodilative activity of adrenomedullin in the pulmonary vascular bed of the intact cat [19] and the rat [21]. The six-membered ring structure formed by an intermolecular disulphide linkage is probably key to the actions of adrenomedullin, but this needs further experimentation.

Another recent study indicated that adrenomedullin may inhibit the activation of inflammatory biochemical pathways caused by the exudation of plasma proteins into bronchial interstitial tissue. Adrenomedullin suppresses the production of cytokine-induced neutrophil chemoattractant, a member of the interleukin-8 (IL-8) family, by increasing cAMP levels in alveolar macrophages [22]. How is IL-8, a potent proinflammatory cytokine initially identified as a chemoattractant for neutrophils, related to asthmatic changes? A previous study showed that IL-8 induces eosinophil migration through the endothelium and epithelium as a potent mediator of eosinophil chemotaxis [23]. Intradermal injection of recombinant human IL-8 causes tissue eosinophilia in the guinea-pig in vivo

Table 1. - Mean blood pressure before and after adrenomedullin (ADM) treatment with and without $L-N^{G}$-nitroarginine methethyl ester (L-NAME) or L-NAME+L-arginine (L-Arg) pretreatment

\begin{tabular}{lcccccc}
\hline & \multicolumn{5}{c}{ Blood pressure mmHg } \\
\cline { 2 - 7 } & ADM & ADM 30 $\mu \mathrm{g} \cdot \mathrm{kg}^{-1}$ & ADM (1-25) & ADM (22-52) & ADM+L-NAME & ADM+L-NAME+L-Arg \\
\hline Before ADM & $52.08 \pm 10.83$ & $51.83 \pm 1.81$ & $59.66 \pm 7.26$ & $53.75 \pm 8.29$ & $92.83 \pm 19.02$ & $55.63 \pm 8.00$ \\
After ADM & $37.09 \pm 3.63^{*}$ & $41.33 \pm 3.21^{* *}$ & $52.00 \pm 8.14$ & $50.62 \pm 6.68$ & $62.39 \pm 9.48^{* *}$ & $49.58 \pm 7.59$ \\
\hline
\end{tabular}

Data are presented as mean \pm SD. Concentrations used, unless otherwise indicated, were as follows: ADM: $100 \mu \mathrm{g} \cdot \mathrm{kg}^{-1}$; L-NAME: 10 $\mathrm{mg} \cdot \mathrm{kg}^{-1}$; and L-Arg: $100 \mathrm{mg} \cdot \mathrm{kg}^{-1}$. $^{*}: \mathrm{p}<0.05 ;{ }^{* *}: \mathrm{p}<0.01$ versus before ADM. 
[24], and upregulated expression of IL-8 mRNA and IL-8 in freshly isolated eosinophils from asthmatic patients [25]. Human lung immunoglobulin E-mediated allergic responses increase the concentration of IL- 8 sufficiently to promote neutrophil and eosinophil migration through naked filters and endothelial and pulmonary epithelial cell monolayers in vitro [26]. This information and a report that IL-8 concentration is markedly increased in the bronchoalveolar lavage fluid of asthmatic patients suggest that IL-8 may be closely related to lung eosinophilia as seen in bronchial asthma [27]. These facts give rise to the possibility that adrenomedullin partially regulates the activation of inflammatory biochemical pathways, demonstrating its usefulness as a powerful anti-inflammatory agent.

In conclusion, this is the first study to demonstrate the inhibitory effects of inhaled adrenomedullin on both antigen-induced airway microvascular leakage and bronchoconstriction. These effects may be closely related to the structure of the adrenomedullin molecule. Further experimental and clinical studies of adrenomedullin in bronchial asthma should be encouraged.

Acknowledgements. The authors would like to thank T. Hayakawa (Internal Medicine II, Nagoya University School of Medicine) for encouragement throughout the study.

\section{References}

1. Kitamura K, Kangawa K, Kawamoto M, et al. Adrenomedullin: a novel hypotensive peptide isolated from human pheochromocytoma. Biochem Biophys Res Commum 1993; 192: 553-560.

2. Kitamura K, Sakata S, Kangawa K, Kojima H, Matsuo H, Eto T. Cloning and characterization of cDNA encoding a precursor for human adrenomedullin. Biochem Biophys Res Commum 1993; 194: 720-725.

3. Sugo S, Minamino N, Kangawa K, et al. Endothelial cells actively synthesize and secrete adrenomedullin. Biochem Biophys Res Commum 1994; 201: 1160-1166.

4. Sugo S, Minamino N, Shoji $\mathrm{H}$, et al. Production and secretion of adrenomedullin from vascular smooth muscle cells: augmented production by tumor necrosis factor- $\alpha$. Biochem Biophys Res Commum 1994; 203: 719-726.

5. Martinez A, Miller MJ, Unsworth EJ, Siegfried JM, Cuttitta F. Expression of adrenomedullin in normal human lung and in pulmonary tumors. Endocrinology 1995; 136: 4099-4105.

6. Kapas S, Catt KJ, Clark AJL. Cloning and expression of cDNA encoding a rat adrenomedullin receptor. $J$ Biol Chem 1995; 270: 25344-25347.

7. Kato J, Kitamura K, Kangawa K, Eto T. Receptors for adrenomedullin in human vascular endothelial cells. Eur $J$ Pharmacol 1995; 289: 383-385.

8. Persson CGA. Role of plasma exudation in asthmatic airways. Lancet 1986; 1: 1126-1128.

9. Ohbayashi H, Suito H, Takagi K. Compared effects of natriuretic peptides on ovalbumin-induced asthmatic model. Eur J Pharmacol 1998; 346: 55-64.

10. Shell DA, Vari RC, Samson WK. Adrenomedullin: a new- ly discovered hormone controlling fluid and electrolyte homeostasis. Trends Endocrinol Metab 1996; 7: 7-13.

11. Kanazawa H, Kurihara N, Hirata K, Kudoh S, Kawaguchi T, Takeda T. Adrenomedullin, a newly discovered hypotensive peptide, is a potent bronchodilator. Biochem Biophys Res Commum 1994; 205: 251-254.

12. Persson MG, Gustafsson LE. Allergen-induced airway obstruction in guinea-pigs is associated with changes in nitric oxide levels in exhaled air. Acta Physiol Scand 1993; 149: 461-466.

13. Alving K, Weitzberg E, Lundberg JM. Increased amount of nitric oxide in exhaled air of asthmatics. Eur Respir $J$ 1993; 6: 1368-1370.

14. Högman M, Frostell CG, Hedenström H, Hedenstierna G. Inhalation of nitric oxide modulates adult human bronchial tone. Am Rev Respir Dis 1993; 148: 1474-1478.

15. Miura M, Ichinose M, Kageyama N, et al. Endogenous nitric oxide modifies antigen-induced microvascular leakage in sensitized guinea-pig airways. J Allergy Clin Immunol 1996; 98: 144-151.

16. Ikeda U, Kanbe T, Shimada K. Adrenomedullin increases inducible nitric oxide synthase in rat vascular smooth muscle cells stimulated with interleukin-1. Hypertension 1996; 27: 1240-1244.

17. Rogers DF, Boschetto P, Barnes PJ. Plasma exudation: correlation between Evan blue dye and radiolabelled albumin in guinea pig airways in vivo. J Pharmacol Methods 1989; 21: 309-315.

18. Eguchi S, Hirata Y, Kano H, et al. Specific receptors for adrenomedullin in cultured rat vascular smooth muscle cells. FEBS Lett 1994; 340: 226-230.

19. Lippon H, Chang JK, Hao Q, Summer W, Hyman AL. Adrenomedullin dilates the pulmonary vascular bed in vivo. J Appl Physiol 1994; 76: 2154-2156.

20. Shimekake Y, Nagata K, Ohta S, et al. Adrenomedullin stimulates two signal transduction pathways, cANP accumulation and $\mathrm{Ca} 2+$ mobilization, in bovine aortic endothelial cells. J Biol Chem 1995; 270: 4412-4417.

21. Gumusel B, Hao Q, Hyman AL, et al. Analysis of responses to adrenomedullin-(13-52) in the pulmonary vascular bed of rats. Am J Physiol 1998; 274: H1255-H1263.

22. Kamoi H, Kanazawa H, Hirata K, Kurihara N, Yano Y, Otani S. Adrenomedullin inhibits the secretion of cytokine-induced neutrophil chemoattractant, a member of the interleukin-8 family, from rat alveolar macrophages. Biochem Biophys Res Commum 1995; 211: 1031-1035.

23. Erger RA, Casale TB. Interleukin-8 is a potent mediator of eosinophil chemotaxis through endothelium and epithelium. Am J Physiol 1995; 268: L117-L122.

24. Collins PD, Weg VB, Faccioli LH, Watson ML, Moqbel R, Williams TJ. Eosinophil accumulation induced by human interleukin-8 in the guinea-pig in vivo. Immunology 1993; 79: 312-318.

25. Simon UE, Yousefi S, Weber M, et al. Human peripheral blood eosinophils express and release interleukin-8. Pathogenesis 1995; 107: 124-126.

26. Erger RA, Casale TB. Interleukin-8 plays a significant role in IgE-mediated lung inflammation. Eur Respir $J$ 1998; 11: 299-305.

27. Nocker RET, Schoonbrood DFM, Von de Graaf EA, et al. Interleukin-8 in airway inflammation in patients with asthma and chronic obstructive pulmonary disease. Int Arch Allergy Immunol 1996; 109: 183-191. 